\title{
Strong negative effect of diurnal rainfall on nocturnal activity of a wandering spider in Central Amazonia
}

\author{
Marlus Queiroz \& Thierry R. Gasnier \\ Departamento de Biologia, Universidade Federal do Amazonas. Av. Gal. Rodrigo OtaÏvio J. Ramos 3000, Manaus \\ (AM), Brasil; marlusqazoo@gmail.com, trjgasnier@gmail.com
}

Received 19-IX-2016. Corrected 30-III-2017. Accepted 03-V-2017.

\begin{abstract}
Rainfall is a common phenomenon in tropical forests influencing the behavior of many animals, however, little is known about its post-occurrence effect on behavior. We investigated the effect of diurnal rainfall on the nocturnal activity of the wandering spider species Phoneutria reidyi in nights without rainfall. Our study included two different areas and periods: a coconut plantation, located $108 \mathrm{~km}$ from the city of Manaus, containing an area of $80 \times 80 \mathrm{~m}$ with 105 palms, from July 2014 to July 2015; and an area of $80 \times 80 \mathrm{~m}$ in a rainforest fragment in Manaus, from December 2015 to March 2016. Each night, we counted active spiders (found outside refugees) searching carefully on the vegetation and on the ground using a headlamp between 19:00-00:00. Spiders were not captured to avoid the effect of disturbance, and were measured by approaching a caliper rule. We used an index to measure the diurnal rainfall effect (DRE) which was the percentage of change in the number of active spiders at night after a diurnal rainfall, considering $100 \%$ the number of spiders active at the previous or following night, without previous rainfall during the day. This pairwise approach was used to avoid seasonal bias and included 15 pairs of nights in the plantation, and 15 pairs in the forest. A total of 2243 active spiders were counted. The number of active spiders was always smaller in nights after diurnal rainfall, with a mean reduction of $53.4 \%$. The abundance of active spiders reduced significantly in both areas after a diurnal rainfall, and the effect was not different between areas. Larger spiders (mostly adults) reduced their activity $(-62.8 \%$ ) more than smaller spiders (juveniles, $-48.5 \%$ ). The amount of rainfall during the day had no effect on the nocturnal activity, i.e., the effect of strong diurnal rainfall is similar to the effect of a weak rainfall. The air temperature did not change significantly at night after diurnal rainfalls. The seasonality of rainfall apparently has a weak or absent effect on the abundance of $P$. reidyi, which was approximately constant through one year. We believe that the moisture, which may affect the chemical cues of prey, is the major cause to reduce the active spiders after rainfall, but we discuss other potential causes. Smaller individuals are probably more active under less favorable conditions due to the stronger need of food for growing. If this effect of rainfall on the behavior is common for wandering spiders in general, the rainfall events may have important consequences for the entire community of arthropods and small vertebrates. We suggest that studies based on relative abundance of spiders should take in account this potential effect in collection and analysis of data. Rev. Biol. Trop. 65 (3): 1152-1160. Epub 2017 September 01.
\end{abstract}

Key words: Phoneutria reidyi, rainforest, behavior, censuses, venomous spiders.

Rainfall can alter the foraging activity of animals by precluding the visual or tactile perception of prey or predators nearby, or by hindering the mobility of small animals (e.g., Gibbons \& Bennett, 1974; Stamps, 1976; Hilton, Ruxton \& Cresswell, 1999; Wallace, 2001; Powell, Brightwell, \& Silverman, 2009). Even after rainfall, foraging may still be influenced by excess moisture in the substrate with concealment of chemical cues of prey and predators (Willians, 1987; Wilder, Devito, Persons, \& Rypstra, 2005), however, studies on the posterior effects of rainfalls on the behavior of animals remain scarce.

Studies on the influence of rainfall on the "activity-densities" of spiders have been 
usually on long term temporal scale, weeks, months, rainy season versus dry season, and have made inferences on the effects of rainfall in the temporal variation of the abundance and mortality of the spiders, on the seasonality of resources or risks, and in the life cycle (e.g., Barth, Seyfarth, Bleckmann, \& Schüch, 1988; Wise, 1993; Gasnier, Höfer, \& Brescovit, 1995; Spiller \& Schoener, 1995; Gasnier \& Höfer, 2001; Romero \& Vasconcellos-Neto, 2003; Lensing, Todd, \& Wise, 2005; Carvalho et al., 2015). As "activity-densities" are numbers of spiders obtained by censuses or traps, a variation in the short term in these numbers in a determinate area is more likely to indicate changes in behavior than in density (Gasnier et al., 1995). The behavior of spiders can be influenced by environmental variables, such as temperature, light intensity and moisture/rainfall (e.g., Barth et al., 1988; Wise, 1993; Zaller et al., 2014; Chai \& Wilgers, 2015), however, we have found no study on the effect of diurnal rainfall on the nocturnal activity of spiders.

Wandering spiders are abundant in most habitats and are considered model organisms for population and community studies (Wise, 1993). In the Neotropical and African forests, the Ctenidae family has several medium to large species that are among the major nocturnal predators of arthropod fauna, and small vertebrates in the understory (e.g., Gasnier \& Höfer, 2001; Jocqué, Samu, \& Bird, 2005; Rego, Venticinque, \& Brescovit, 2005). Despite their abundance, the habitat complexity makes difficult the study of some species in the natural environment. We have found a population of the species Phoneutria reidyi, a large wandering spider, in high density, in a much less complex environment, a coconut plantation in central Amazonia. In our preliminary observations, we noticed that the number of active spiders varied greatly from night to night, and it was evident that rainfall during the day could be a cause of this variation, which was the origin of this study. Later, we have found a second area with a very dense population of the same species in a tropical forest, which allowed a comparison of the results of the plantation with a natural environment.

The spiders of the genus Phoneutria (Perty, 1833), known as "aranhas-armadeiras", "banana spider" or "Brazilian wandering spiders" belong to the family Ctenidae and are distributed over most of South and Central America (Simó \& Brescovit, 2001; Martins \& Bertani, 2007; Hazzi, 2014). They are large, dangerously venomous to humans, and are also common in anthropogenic environments, such as plantations, gardens and homes (Cardoso, França, Wen, Malaque, \& Haddad-Jr, 2009; Torres-Sanchez \& Gasnier, 2010; Hazzi, 2014). Two species of the genus, P. reidyi (F.O. Pickard-Cambridge, 1897) and P. fera (Perty, 1833 ) coexist in "terra firme" (non-inundated) forests in most Amazonia (Martins \& Bertani, 2007). They are nocturnal and can be found on vegetation (frequently on palm trees) and on the ground in primary forest areas, where they prey arthropods, mainly cockroaches, crickets, moths and spiders. The abundance of the $P$. reidyi is correlated with the abundance of palms in the forest, which could be a strategy to avoid the intraguild predation by $P$. fera (Torres-Sanchez \& Gasnier, 2010), and possibly makes $P$. reidyi more abundant in coconut plantations in the region. More details on their ecology are described by Torres-Sanchez and Gasnier (2010).

Our main objective was to test the hypothesis that diurnal rainfall affects the number of active $P$. reidyi at night, and we also evaluated: a) if the effect of the diurnal rainfall on the number of active spiders was different between large (adults and sub-adults) and small (juveniles and sub-adults) individuals; b) if the effect changed among different habitats plantation and forest; c) if this effect depended on the intensity of rainfall during the day; d) if the difference could be related to a change in the temperature after the rain.

\section{MATERIALS AND METHODS}

Study Area: We conducted the study between July 2014 and July 2015 in a dwarf 
coconut tree plantation at "Fazenda Jabuti" (2॰43’21” S - 59॰30’33” W), Rio Preto da Eva, and between December 2015 and March 2016 in the forest fragment of the campus of the Universidade Federal do Amazonas - UFAM $\left(03^{\circ} 04^{\prime} 34^{\prime \prime} \mathrm{S}-59^{\circ} 57^{\prime} 30^{\prime}\right.$ ' W) in the city of Manaus, both in the Amazonas State in Brazil. The cultivation area had 105 coconut trees in an area of approximately $80 \times 80 \mathrm{~m}$, with spacing between neighbor trees of $5 \mathrm{~m}$. around the trees on the ground there was bare soil, grass and low undergrowth. Dead palm leaves remained close to the tree bases and were a common refuge for the spiders and other animals. The forest fragment of the Federal University of Amazonas is one of the largest urban fragments of the world, with approximately 776 hectares, relatively well preserved (Marcon, Crus, Menin, Carolino, \& Gordo, 2012). In this fragment, we delimited our second study site with approximately $80 \times 80 \mathrm{~m}$ in a swamp forest (or "baixio") close to a small creek, which is a habitat where $P$. reidyi is more common in "terra firme" forests (Torres-Sanchez \& Gasnier, 2010). In this swamp forest the palm trees "paxiuba" (Socratea exorrhiza) were abundant.

Censuses of spiders: We made nocturnal (between 19:00-0:00) censuses of active spiders with headlamps, always on nights without rainfall during the censuses. We have not captured spiders during the censuses to avoid the effect of disturbance from one night to the next, and we considered as active all visually exposed spiders, i.e., out of their refuges, carefully searching for the spiders on all coconut trees and on the ground around them in the coconut plantation; and on the vegetation below $2 \mathrm{~m}$ and on the soil in the forest. Preliminary collections showed that only the species of Phoneutria in both study areas was P. reidyi, but we always checked the identification in the field based on the palps and abdomen design pattern (Martins \& Bertani, 2007), this method can be used effectively to identify juveniles and adults of $P$. reidyi in ecological studies (Torres-Sanchez \& Gasnier, 2010). The species P. fera, which is also common in the region, has a different design pattern and was not found in both sites during the study.

Considering the size of the smaller adults from a previous study in the same region (Torres-Sanchez \& Gasnier, 2010), we divided the spiders in two size categories: "Large" - with prosoma length (PL) $\geq 12 \mathrm{~mm}$ (sub-adult and adult) and "Small", with PL $<12 \mathrm{~mm}$ (young and sub-adult). For each spider found, we recorded the type of substrate and the behavior at the moment of observation (stopped or moving, eating, interacting with other individual) and the size of the prosome, measured with a precision caliper (millimeters) positioned as close as possible $(\sim 1 \mathrm{~cm})$ from the animal. The censuses were made searching carefully each of the 105 numbered coconut trees and on the ground in the plantation, and searched the plants and the ground of an area of approximately the same size, in both areas during about 3 to 4 hours, using a head torch (Bushnell-H250L). We deposited voucher specimens from both places in the invertebrate collection of "Coleção Zoológica" of Instituto Nacional de Pesquisas da Amazônia (INPA).

To test the effect of diurnal rainfall (during the morning and/or afternoon), on the nocturnal activity, we formed 30 pairs of consecutive nights. To evaluate the effect of rainfall in the natural habitat of spiders, we conducted 15 pairs in both, an open area of coconut trees plantation and in a forest of "terra firme". We made successive censuses until a pair was formed (e.g., wet, wet, wet, dry = pair), and discarded the data of the nights before the pair in the pairwise analysis. The use of pairs for comparisons between subsequent days differing in diurnal rainfall, is a strategy to reduce unexplained variance (Quinn \& Keough, 2003), and allows discriminating the immediate effect of rainfall, from the effect of confounding factors that change in a scale of weeks or months (e.g., amount of prey and predators, medium term climate situation, reproductive season, structure of sizes of the population).

We calculated the Diurnal Rainfall Effect (DRE) with the formula: DRE $=($ NSwet-NSdry) *100/NSdry, where: NSwet is the number 
of spiders in nights with previous diurnal rainfall and NSdry is the number of spiders in nights without previous diurnal rainfall. A negative DRE indicates a reduction in the number of spiders in "wet" nights compared to the respective "dry" night. The minimum number of spiders counted in a pair to calculate the DRE was 10. We used the "Accelerated BiasCorrected" Bootstrapping technique (Manly, 2007) with 9999 randomizations to generate confidence intervals (95\% CIs) for the mean DRE in the plantation and in the forest. Bootstrapping allows the determination of CIs, even in the absence of normal distribution (Efron, 1982). We considered that the effect of the occurrence of rainfall significant when the 95 $\%$ CIs of the mean of DRE did not include zero. We used the Fisher Pitman Permutation Test based on 9999 Monte Carlo randomizations (a resampling statistic equivalent to the Wilcoxon Mann Whitney Rank Sum Test, Manly, 2007) to compare the DREs in the plantation and in the forest, and to compare the DREs of "Large" spiders and "Small" spiders. We determined the mean and $95 \%$ CI (by bootstrap) of the difference of air temperature between the nights after a diurnal rainfall compared with the air temperature after a clear day, to evaluate if this change in temperature is sufficient to be affect the behavior of the spiders. We used least square linear regression to evaluate the effect of the intensity of the rainfall during the day on the DRE. A descriptive evaluation of the temporal variation in the rainfall and abundance of spiders during one year, was presented for the coconut plantation population from data of nights not preceded by rainfall during the day. Data to evaluate the annual variation in the abundance of spiders in the rainforest was not collected because the decision to include a second habitat was taken close to the end of the study. The air temperature in each night used for the analyses was the mean temperature of three moments: 18:00, 21:00 and 00:00. The rainfall during the day was the rainfall from 6:00 to 18:00. Statistical analyses were performed with the software program R (R Core Development Team, 2016), the bootstrap with the function "bcanon" from the package "bootstrap" (Leisch, 2015) the permutation test with the function "oneway_test" (two sample Fisher Pitman Permutation) from the package "coin" (Hothorn, Hornik, Mark, Wiel, \& Zeileis, 2008), and the linear regression with the function "lm" from the package "stats" (R Core Development Team, 2016). The significance level adopted was $\alpha=0.05$.

Rainfall and temperature data were obtained from the National Institute of Meteorology (INMET) from a weather station situated on the "Rio Urubu", located $30 \mathrm{~km}$ from the plantation and from another station located $4 \mathrm{~km}$ from the study, at the Universidade Federal do Amazonas.

\section{RESULTS}

We made 2243 observations of active spiders during all nights of the study, 1821 considering only the nights used for the pairwise comparisons, 1056 in the coconut plantation and 765 in the forest area. The temporal variation in the number of spiders counted by night throughout the year in the plantation was based on 29 nights without previous rainfall in which 1280 spiders were found and 29 nights with previous rainfall.

The number of active spiders during "wet" nights (preceded by rainfall) was lower than the number of spiders during "dry" nights (without diurnal rainfall) in all 30 pairs of nights; a 50 $\%$ reduction in absolute numbers in the coconut plantation (704 vs. 352 ), and $56.7 \%$ in the forest (534 vs. 231). The Diurnal Rainfall Effect (DRE) showed a strong and significant reduction in the activity of the spiders in both areas during "wet" nights (plantation mean DRE $=-49.5 \%$; Lower Confidence Limit $=-53.5$ $\%$; Upper Confidence Limit $=-46.1 \%$; forest mean DRE $=-54.8 \%$; Lower Confidence Limit $=-60.0 \%$; Upper Confidence Limit $=-49.8 \%$ ). The difference in DREs between the plantation and forest areas was not significant (Fig. 1A: Fisher-Pitman Permutation, $\mathrm{Z}=-1.57 ; \mathrm{P}=$ 0.121 ). The larger spiders decreased their activity in nights after diurnal rainfall significantly 
more than the smaller spiders (Fig. 1B: respectively $62.8 \%$ and $48.5 \%$, Fisher-Pitman Permutation, $\mathrm{Z}=2.68 ; \mathrm{P}=0.005)$. Although the occurrence of rainfall reduced the activity of the spiders, we have found no relationship between the amount of rainfall during the day, and the activity reduction intensity measured with the DRE index (Least Square Linear regression: $\mathrm{F}_{1,28}=0.58, \mathrm{P}=0.45 ; \mathrm{R}^{2}=-0.01$ ).

There was no significant change in the nightly mean air temperature after rainfall. The mean difference in temperature increased slightly $\left(0.1{ }^{\circ} \mathrm{C}\right)$ in the plantation $(95 \% \mathrm{CI}$ : Lower Confidence Limit $=-1.4{ }^{\circ} \mathrm{C}$; Upper Confidence Limit $=1.1{ }^{\circ} \mathrm{C}$ ) and decreased slightly $\left(-1.0^{\circ} \mathrm{C}\right)$ in the forest $(95 \% \mathrm{CI}$ : Lower Confidence Limit $=-2.0^{\circ} \mathrm{C}$; Upper Confidence Limit $=0.4{ }^{\circ} \mathrm{C}$ ).

The temporal variation in the abundance of spiders was much clearer excluding data

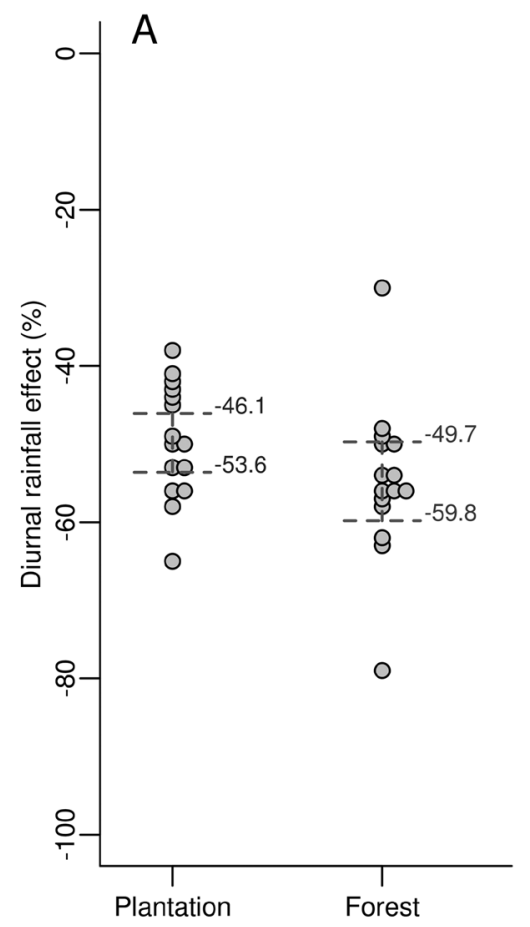

of nights after diurnal rainfall (Fig. 2). The rainfall was low from July to December 2014, and high from January to June in 2015, which is normal in Central Amazonia. The number of spiders observed in nights without previous diurnal rainfall, remained relatively constant during this period, except for some lower scores in September 2014, at the end of the dry season. Therefore, high rainfall apparently does not reduce the population of $P$. reidyi.

\section{DISCUSSION}

The reduction in the number of $P$. reidyi active outside refuges after diurnal rainfall was strong, but it may still underestimate the total indirect effect of rainfall. It is likely that the displacement of the fewer active spiders will also be reduced in this situation. We did not measure

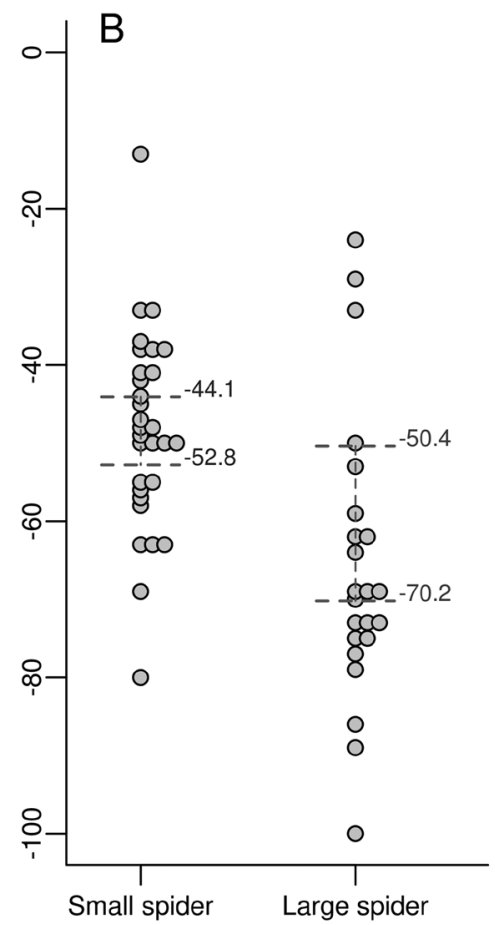

Fig. 1. Effect of diurnal rainfall (DRE) on the amount of active Phoneutria reidyi spiders at night: a) in two study sites: a coconut plantation and a rainforest; b) comparing "small" spiders (prosoma length $<12 \mathrm{~mm}$ ) and "large" spiders (prosoma length $\geq 12 \mathrm{~mm}$ ). The DRE is the change in the percentage in the number of spiders active in a night after a diurnal rainfall considering $100 \%$ the number of spiders active at the previous or following night without rainfall during the day. A negative DRE means reduced activity in days with rainfall. The dashed line represents the $95 \%$ confidence interval of DRE. The effect is considered significant when the $95 \%$ CI does not include zero. 


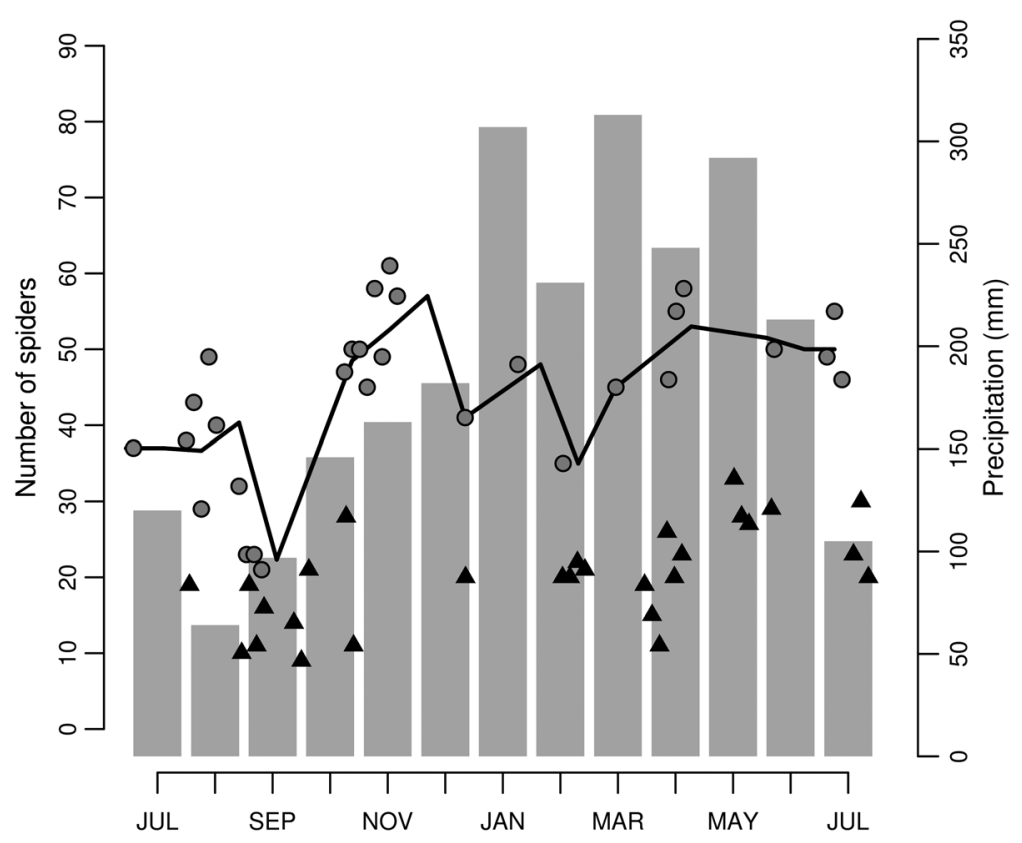

Fig. 2. Variation in the number of active spiders at nights (gray circles) and monthly rainfall (bars) from July 2014 to July 2015. The trend line connects the monthly average in the number of spiders found active in the nights without previous rainfall during the day (circles). If the data from nights with diurnal rainfall (dark triangles) were included, there would be much more noise in the pattern.

the direct effect of rainfall on the spiders' activity, but we observed that the number of spiders is still lower during rains. Considering that rainfall is frequent in this region, we concluded that precipitation is an important factor in the ecology of this species.

Some spiders, including other species of the Ctenidae family, can sense chemical cues of prey and predators (Wilder et al., 2005, Portela, Willemar, \& Gasnier, 2013), and the rainfall can wash these chemical cues, so that it can be more economic and less risky to decrease activity when the environment is humid. To us, this seems to be the cause of change in the activity of $P$. reidyi, but there are other possibilities. Humidity may change the substrate properties to transmit vibrations (Barth, 2002), potentially interfering in the foraging activity. The surface tension of water on wet surfaces can make the displacement more difficult and risky. Frogs are important predators of spiders (Teixeira \& Coutinho, 2002), and there is greater risk of predation by frogs on rainy nights (Gibbons $\&$ Bennett, 1974). The reduction in activity varied according to the size of the spiders. Possibly the need for food for growing youngsters makes them more likely to be active under unfavorable conditions.

The forest tends to retain moisture for longer, so we expected to find a stronger and longer effect of rainfall on spiders in this environment. However, P. reidyi's activity was not different between forest and plantation. This result suggests that the effect of previous rainfall does not depend on the type of habitat (open or closed). Temperature is a factor that affects the behavior of spiders in some habitats (e. g., Barth et al., 1988, Chai \& Wilgers, 2015), however, in this tropical study, there were no significant changes in air temperature which could explain the change in the number of active spiders between the pairs of nights.

The abundance of $P$. reidyi in the forest is relatively low compared to the abundance 
of other sympatric wandering spiders; therefore, the behavioral variation observed probably does not strongly affect its potential prey populations. However, it seems unlikely that this change in behavior is restricting to one species. If a reduction in activity is an effect of the dilution of chemical clues, this dilution would also reduce the activity of other wandering spiders sensible to chemical clues. This change in behavior in many wandering spiders would have important consequences for the whole community of arthropods and small vertebrates that are their potential preys. Several social insects, such as ants and termites, have a swarming behavior after heavy diurnal rains (Hölldobler \& Wilson, 1990, Medeiros, Bandeira, \& Martius, 1999). Winged termites are common prey of wandering spiders in this forest (personal observation), and post-rains swarms could be a way of reducing this predation. Other potential prey could also take advantage of a reduced spider activity to carry out higher risk activities, such as long displacements, reproductive activities, and establishment of new colonies.

There are absolute and relative methods to study factors affecting the abundance of animals. The absolute density estimated by distance sampling models is considered reliable for the study of spiders' abundance (Jocqué et al., 2005), and it is presumably not influenced by the weather, however, this method has some assumptions that are not always fulfilled (Thomas et al., 2010). Therefore, relative abundance estimates are still important, however, the potential effect of rainfall should be considered. In this study, the exclusion of data obtained on days with diurnal precipitation allowed a drastic reduction in statistical noise in the analysis of annual temporal variation of abundance. If strong reduction of activity after precipitation is a common phenomenon in nocturnal spiders, censuses after days with precipitation should be avoided or excluded from the analysis to allow a better evaluation in studies of the spatial and temporal variation of abundance.

\section{ACKNOWLEDGMENTS}

We thank Sergio L. Silva for help with graphics in the program R, Hubert Höfer for comments on a previous version of the manuscript and Andrea Waichman for the elaboration of the Resumen. Two anonymous reviewers contributed greatly to the improvement of the manuscript. This paper is part of the first author's master's thesis in the graduate program "Biological Diversity" of the Federal University of Amazonas (UFAM). We appreciate the financial support of Coordination of Superior Level Staff Improvement (CAPES) scholarship to the first author. Climate data were obtained from the National Institute of Meteorology of Brazil (INMET).

\section{RESUMEN}

Fuerte efecto negativo de las lluvias diurnas sobre la actividad nocturna de una araña errante en la Amazonía Central. La lluvia es un fenómeno común en los bosques tropicales que influye en el comportamiento de muchos animales, sin embargo, se sabe poco sobre su efecto posterior en el comportamiento. Se investigó el efecto de la lluvia diurna sobre la actividad nocturna de la especie de araña errante Phoneutria reidyi en noches sin lluvia, durante un año en una plantación ubicada a $108 \mathrm{~km}$ de la ciudad de Manaus, con área de 80 x $80 \mathrm{~m}$ y 105 palmeras y durante cuatro meses en un área de 80 x $80 \mathrm{~m}$ en un fragmento de selva en Manaus. En cada noche entre 19:00 y 0:00, contamos a las arañas activas (encontradas fuera de refugios) buscando cuidadosamente en la vegetación y en el suelo, usando una linterna de cabeza. Las arañas no fueron capturadas para evitar el efecto de la alteración, y fueron medidas acercándo una regla de calibrar a ellas. Se utilizó un índice para medir el efecto de la lluvia diurna (ELD), que fue el porcentaje de cambio en el número de arañas activas en una noche después de una lluvia diurna considerando el $100 \%$ el número de arañas activas en la noche anterior o siguiente, sin lluvia durante el día. Este enfoque pareado se utilizó para evitar sesgo estacional e incluyó 15 pares de noches en la plantación y 15 pares en la selva. Se contó un total de 2243 arañas activas. El número de arañas activas fue siempre menor en las noches después de la lluvia diurna, con una reducción media del 53.4\%. La abundancia de arañas activas se redujo significativamente en ambas áreas después de una lluvia diurna, y el efecto no fue diferente entre las áreas. Las arañas mayores (en su mayoría adultos) redujeron su actividad (-62.8\%) más que las arañas menores (juveniles, $-48.5 \%$ ). La cantidad de lluvia durante el día no tuvo efecto sobre la actividad nocturna, i. e., el efecto lluvias fuertes fue semejante al efecto de las débiles. 
La temperatura del aire no cambió significativamente en la noche después de lluvias diurnas. La variación de las lluvias durante el año parece tener un efecto débil o ausente en la abundancia de $P$. reidyi, que fue aproximadamente constante durante un año. Creemos que la humedad, que puede afectar las señales químicas de las presas, es la principal causa para reducir las arañas activas después de la lluvia, pero discutimos otras causas potenciales. Las arañas menores probablemente están más activas en condiciones menos favorables debido a la mayor necesidad de alimento para crecer. Si este efecto de la lluvia sobre el comportamiento es común para las arañas errantes, los eventos de lluvia pueden tener consecuencias importantes para toda la comunidad de artrópodos y pequeños vertebrados. Sugerimos que los estudios basados en la abundancia relativa de arañas deben tener en cuenta este efecto potencial en la recolecta y análisis de datos.

Palabras clave: Phoneutria reidyi, selva tropical, comportamiento, censos, araña venenosa.

\section{REFERENCES}

Barth, F. G. (2002). Spider senses - technical perfection and biology. Zoology, 105, 271-285.

Barth, F. G., Seyfarth, E. A., Bleckmann, H., \& Schüch, W. (1988). Spiders of the genus Cupiennius Simon 1891 (Araneae: Ctenidae). Oecologia, 77, 187-193.

Cardoso, J. L. C., França, F. O. S., Wen, F. H., Malaque, C. M. S., \& Haddad-Jr, V. (2009). Animais Peçonhentos no Brasil: Biologia Clínica e Terapêutica dos Acidentes. $2^{\mathrm{a}}$ Edição. São Paulo, Brasil: Sarvier.

Carvalho, L. S., Sebastion, N., Araújo, H. F. P., Dias, S. C., Venticinque, E., Brescovit, A. D., \& Vasconcellos, A. (2015). Climatic variables do not directly predict spider richness and abundance in semiarid Caatinga vegetation, Brazil. Environmental Entomology, 44, 54-63.

Chai, Y. Q., \& Wilgers, D. J. (2015). Effects of temperature and light levels on refuge use and activity in the wolf spider Rabidosa punctulata. Transactions of the Kansas Academy of Science, 118 (3-4), 194-200.

Efron, B. (1982). The jackknife, the bootstrap and other resampling plans. Philadelphia, Pennsylvania, USA: Society for Industrial and Applied Mathematics.

Gasnier, T. R., \& Höfer, H. (2001). Patterns of abundance of four species of wandering spiders (Ctenidae: Ctenus) in a forest in central Amazonia. Journal of Arachnology, 29, 95-103.

Gasnier, T. R., Höfer, H., \& Brescovit, A. D. (1995). Factors affecting the "activity density" of spiders on tree trunks in an Amazonian rainforest. Ecotropica, 12, 69-77.
Gibbons, J. W., \& Bennet, D. H. (1974). Determination of Anuran Terrestrial Activity Patens by a Drift Fence Method. Copeia, 236-243.

Hazzi, N. A. (2014). Natural history of Phoneutria boliviensis (Araneae: Ctenidae): habitats, reproductive behavior, postembryonic devolopment and prey-wrapping. Journal of Arachnology, 42, 303-310.

Hilton, G. M., Ruxton, G. D., \& Cresswell, W. (1999). Choice of foraging area with respect to predation risk in redshanks: The Effects of Weather and Predator Activity. Oikos, 87, 295-302.

Hölldobler, B., \& Wilson, E. O. (1990). The ants. Massachusetts, USA: Cambridge.

Hothorn, T., Hornik, K., Mark, A., Wiel, V., \& Zeileis, A. (2008). Implementing a Class of Permutation Tests: The coin Package. Journal of Statistical Software, $288,1-23$.

Jocqué, R., Samu, F., \& Bird, T. (2005). Density of spiders (Araneae: Ctenidae) in Ivory Coast rainforests. Journal of Zoology, 266, 105-110.

Leisch, F. (2015). Bootstrap: Functions for the Book "An Introduction to the Bootstrap". R package version 2. Retrieved from https://CRAN.R-project.org/ package $=$ bootstrap

Lensing, J. R., Todd, S., \& Wise, D. H. (2005). The impact of altered precipitation on spatial stratification and activity-densities of springtails (Collembola) and spiders (Araneae). Ecological Entomology, 30, 194-200.

Manly, B. F. J. (2007). Randomization, Bootstrap and Monte Carlos Methods in Biology. Boca Raton, FL, USA: Chapman \& Hall.

Marcon, J. L., Crus, J., Menin, M., Carolino, O. T., \& Gordo, M. (2012). Biodiversidade fragmentada na floresta do campus da Universidade Federal do Amazonas: Conhecimento Atual e Desafios para a Conservação. In J. L. Marcon, M. Menin, M. G. P. Araújo, \& T. Hrbek. Biodiversidade Amazônica: Caracterização, Ecologia e Conservação. Manaus, Brasil: Editora da Universidade Federal do Amazonas.

Martins, R., \& Bertani, R. (2007). The non-Amazonian species of the Brazilian wandering spiders of the genus Phoneutria Perty, 1833 (Araneae: Ctenidae), with the description of a new species. Zootaxa, $1526,1-36$.

Medeiros, L. G. S., Bandeira, A. G., \& Martius, C. (1999). Termite swarming in the Northeastern Atlantic rain forest of Brazil. Studies on Neotropical Fauna and Environment, 34, 76-87.

Perty, M. (1833). Brasilianische Spinnen. In J. B. de Spix \& F. F. Martius (Eds.), Delectus Animalium Articulatorum quae in itinere per brazilian ann. 1817 et 1820 colligerunt (pp. 191-209). Monachii. 
Pickard-Cambridge, F. O. (1897). On cteniform spiders from the lower Amazons and other regions of North and South America. The Annals and Magazine of Natural History, 19, 52-106.

Portela, E., Willemar, R. H., \& Gasnier, T. R. (2013). Soil type preference and the coexistence of two species of wandering spiders (Ctenus amphora and C. Crulsi: Ctenidae) in a rainforest in Central Amazonia. Journal of Arachnology, 41, 85-87.

Powell, B. E., Brightwell, R. J., \& Silverman, J. (2009). Effect of an invasive and native ant on field population of the black citrus aphid (Hemiptera: Aphididae). Environmental Entomology, 38, 1618-1625.

Quinn, G. P., \& Keough, M. J. (2003). Experimental design and data analysis for biologists. New York: Cambridge University Press.

R core development team. (2016). R: version 3.3.2. The $\mathrm{R}$ project for statistical computing, Vienna, Austria. Retrieved from https://www.r-project.org

Rego, F. N. A. A., Venticinque, E. M., \& Brescovit, A. D. (2005). Densidade de aranhas errantes (Ctenidae e Sparassidae, Araneae) em uma floresta fragmentada. Biota Neotropica, 5(1a), 45-52.

Romero, G. Q., \& Vasconcellos-Neto, J. (2003). Natural history of Misumenops argenteus (Thomisidae): seasonality and diet on Trichogoniopsis adenantha (Asteraceae). Journal of Arachnology, 31, 297-304.

Simó, M., \& Brescovit, A. D. (2001). Revision and cladistic analysis of the neotropical spider genus Phoneutria Perty, 1833 (Araneae: Ctenidae), with notes on related Ctenidae. Bulletin of British Arachnological Society, 122, 67-82.

Spiller, D. A., \& Schoener, T. W. (1995). Long-term variation in the effect of lizards on spider density is linked to rainfall. Oecologia, 103, 133-139.
Stamps, J. A. (1976). Rainfall, activity and social behavior in the lizard Anolis aeneus. Animal Behavior, 24, 603-608.

Teixeira, L. T., \& Coutinho, E. S. (2002). Hábito alimentar de Proceratophrys boiei (Wied) (Amphibia, Anura, Leptodactylidae) em Santa Teresa, Espírito Santo, sudeste do Brasil. Boletim do Museu Biologia Mello Leitão, 14, 13-20.

Thomas, L., Buckland, S. T., Rexstad, E. A., Laake, J. L., Strindberg, S., Hedley, S. L., Bishop, J. R. B., Marques, T. A., \& Burnham, K. P. (2010). Distance software: design and analysis of distance sampling surveys for estimating population size. Journal of Applied Ecology, 47, 5-14.

Torres-Sanchez, M. P., \& Gasnier, T. R. (2010). Patterns of abundance, habitat use and body size structure of Phoneutria reidyi and P. fera (Araneae: Ctenidae) in a Central Amazonian rainforest. Journal of Arachno$\log y, 38,433-440$.

Wallace, R. B. (2001). Diurnal activity budgets of black spider monkeys Ateles chamek, in a Southern Amazonian Tropical forest. Neotropical Primates, 9, 101-107.

Wilder, S. M., Devito, J., Persons, M. H., \& Rypstra, A. L. (2005). The effects of moisture and heat on the efficacy of chemical cues used in predator detection by Pardosa milvina (Araneae: Lycosidae). Journal Arachnology, 33, 857-861.

Williams, S. C. (1987). Scorpion bionomics. Annual Review of Entomology, 32, 275-95.

Wise, D. H. (1993). Spiders in Ecological Webs. New York: Cambridge University Press.

Zaller, J. G., Simmer, L., Santer, N., Tataw, J. T., Formayer, H., Murer, E., Hösch, J., \& Baumgarten, A. (2014). Future rainfall variations reduce abundances of aboveground arthropods in model agroecosystems with different soil types. Frontiers in Environmental Science, 2, 44. 